https://doi.org/10.17816/MAJ191S170-72

\title{
PARAMETERS OF IMMUNITY AND SYSTEMIC INFLAMMATION IN ENDOGENOUS PSYCHOSIS
}

\author{
I.K. Malashenkoval, 2, D.P. Ogurtsov ${ }^{1,2}$, S.A. Krynskiy ${ }^{1}$, N.A. Hailov', E.I. Chekulaeval, \\ N.A. Didkovsky, M.V. Mamoshina', V.L. Ushakov', A.Yu. Morozova ${ }^{3}$, \\ N.V. Zakharova ${ }^{4}$, G.P. Kostyuk ${ }^{4}$ \\ ${ }^{1}$ NRC "Kurchatov Institute", Moscow, Russia; \\ ${ }^{2}$ FSBI FCRC of Physical-Chemical Medicine FMBA of Russia, Moscow, Russia; \\ ${ }^{3}$ Federal Medical Research Centre for Psychiatry and Narcology, Moscow, Russia; \\ ${ }^{4}$ Psychiatric Clinical Hospital No. 1 named after N.A. Alekseev, Moscow, Russia
}

\section{ПАРАМЕТРЫ ИММУНИТЕТА И СИСТЕМНОЕ ВОСПАЛЕНИЕ ПРИ ЭНДОГЕННЫХ ПСИХОЗАХ}

\author{
И.К. Малашенкова ${ }^{1,2}$, Д.П. Огуриов ${ }^{1,2}$, С.А. Крынский ${ }^{1}$, Н.А. Хайлов ${ }^{1}$, \\ Е.И. Чекулаева ${ }^{1}$, Н.А. Дидковский ${ }^{2}$, М.В. Мамошина ${ }^{1}$ В.Л. Ушаков ${ }^{1}$, А.Ю. Морозова ${ }^{3}$, \\ Н.В. Захарова ${ }^{4}$, Г.П. Костюк 4 \\ ${ }^{1}$ НИЦ «Курчатовский Институт», Москва; \\ ${ }^{2}$ ФНКЦ физико-химической медицины ФМБА России, Москва; \\ ${ }^{3}$ ФГБУ «Национальный медицинский исследовательский центр психиатрии и наркологии», Москва; \\ ${ }^{4}$ ГБУЗ «ПГБ № 1 им. Н.А. Алексеева ДЗМ», Москва
}

The aim of the work was to study the factors of natural and adaptive immunity and systemic inflammation in subacute stage of schizophrenia to clarify the role of these systems in the chronization of the disease. 31 patients with the diagnosis of schizophrenia (SCI) with paranoid after 3-4 weeks of therapy were examined. The control group included 16 healthy volunteers. Markers of systemic inflammation and immunity, including key cytokines and lymphocyte subpopulations, were investigated. Increased levels of IgM, C-reactive protein and cortisol in the blood were found in patients with SCI. Also in most cases the content of proinflammatory proteins IL-8, IL-6 and IL-10 was increased. The greatest increase in the levels of systemic inflammation and cytokines was found in patients with first psychotic episode. The content of HT was more often normal, but the level of NT-4 and nerve growth factor $\beta$ (NGF $\beta$ ) in most patients was positively associated with levels of IL-6. At low levels of BDNF a significant increase in levels of CIC, cortisol, IL-8, IL-6 and IL-10, but not Ig were found. Also, in patients with low BDNF symptoms of delusions prevailed, while in cases of normal or elevated BDNF (19 out of 24 cases), in addition to delusions, hallucinations were pronounced. Conclusion. It is believed that antipsychotic drugs reduce systemic inflammation and activity of the immune system. However, we have found signs of severe systemic inflammation, activation and dysfunction of the immune system in patients with SCI after 3-4 weeks of therapy. Preservation of immune disorders and systemic inflammation in patients with SCI despite clinical improvement can participate in the progression of the disease through neuroimmune interactions. Further studies of the trigger mechanisms of chronic immune activation are needed.

Keywords: schizophrenia; neurotrophins; immunity; cytokines; systemic inflammation.

Цель работы - исследование факторов естественного и адаптивного иммунитета и системного воспаления, нейротрофинов (НТ) в подострой стадии заболевания для уточнения роли этих систем в хронизации болезни. Обследовали 31 больного с диагнозом шизофрения (Ш3) $(n=31)$ после $3-4$ недель терапии. Группа сравнения - 16 здоровых добровольцев. У больных ШЗ было обнаружено повышение уровня IgM, C-реактивного белка и кортизола в крови. Также в большинстве случаев увеличивалось содержание провоспалительных белков - IL-8, IL-6 и IFN $\gamma$. Содержание НT чаще было нормальным, однако уровень NT-4 и фактора роста нервов $\beta$ (NGF $\beta$ ) у большинства больных был ассоциирован с содержанием IL-6 и изменялся однонаправленно. При низком уровне BDNF сушественно повышались уровни ЦИК, кортизола, IL-8, IL-6 и IL-10, но не Ig. При этом у больных с низким уровнем BDNF преобладали симптомы бреда. В случае нормального или повышенного уровня BDNF, кроме бредового синдрома, галлюцинаторный синдром был ярко выраженным и длительным. Заключение. Считают, что антипсихотические препараты снижают системное воспаление и активность иммунной системы. Однако нами у больных ШЗ были обнаружены признаки выраженного системного воспаления, активации и дисфункции иммунитета после 3-4 недель терапии. Сохранение иммунных расстройств и системного воспаления у больных ШЗ несмотря на клиническое улучшение может через различные пути нейроиммунных взаимодействий участвовать в прогрессировании заболевания. Необходимы дальнейшие исследования триггерных механизмов хронической иммунной активации.

Ключевые слова: шизофрения; нейротрофины; иммунитет; цитокины; системное воспаление. 
The levels of inflammation markers in blood serum in patients with schizophrenia

\begin{tabular}{|l|c|c|c|}
\hline & $\begin{array}{c}\text { Schizophrenia } \\
\boldsymbol{n}=\mathbf{3 1}\end{array}$ & $\begin{array}{c}\text { Controls } \\
\boldsymbol{n}=\mathbf{1 7}\end{array}$ & $\begin{array}{c}\text { Normal values } \\
\boldsymbol{n}=\mathbf{4 0}\end{array}$ \\
\hline IgA, mg\% & $314.9 \pm 28.51^{*}$ & $296.1 \pm 27.5$ & $205 \pm 15.2$ \\
\hline $\mathrm{IgM}, \mathrm{mg} \%$ & $212.1 \pm 67.2^{*, * *}$ & $119.3 \pm 28.6$ & $122 \pm 30.8$ \\
\hline IgG, mg\% & $1404.7 \pm 100.4$ & $1336.5 \pm 105.3$ & $1215 \pm 140.2$ \\
\hline Circulating immune complexes, c.u. & $112.7 \pm 24.6^{*, * *}$ & $76.76 \pm 10.8$ & $79.3 \pm 6.5$ \\
\hline C-reactive protein, mg/l & $8.3 \pm 3.6^{* * * *}$ & $1.74 \pm 0.75$ & $1.75 \pm 0.15$ \\
\hline Cortisol, nmol/1 & $473.7 \pm 48.7^{*, * *}$ & $344.0 \pm 65.0$ & $322.0 \pm 21.4$ \\
\hline
\end{tabular}

N o t e. * significant $(p<0.05)$ differences with controls; ** significant $(p<0.05)$ differences with normal levels.

Schizophrenia is a multifactorial polymorphic mental disorder with characteristic disorders of thinking and perception [1]. Genetic predisposition and congenital pathology of the brain due to intrauterine hypoxia, infectious diseases and maternal starvation, as well as exogenous factors including social, toxic, infectious (intracellular parasitic infections, viral infections and a number of others) play an important role in the development of SCI [2]. The etiology and pathogenesis are not sufficiently studied, and experimental models of SCI are not adequate enough. It is believed that dysfunction of neurotransmitter interactions affecting dopamine, glutamate, serotoninergic and other systems and neurotrophin deficiency play an important role in the pathogenesis of SCI. There is strong epidemiological, genetic and clinical evidence of immune disorders in schizophrenia. Exacerbations of the disease are accompanied by a high content of a number of proinflammatory cytokines and other markers of systemic inflammation in the CSF and serum, activation of Th2 link of adaptive immunity [3].

We examined 31 patients diagnosed with schizophrenia, after 3-4 weeks of therapy. The control group consisted of 16 people without cognitive impairment. Indicators of healthy volunteers we obtained earlier were also used for reference. The levels of systemic inflammation markers (circulating immune complexes (CIC), C-reactive protein, cortisol), of key cytokines (IL-1 $\beta, \mathrm{TNF} \alpha$, IL-6, IL-8, IL-10, IFNy, soluble receptor of IL-1 $\beta$ - IL-1RA, IL-12 (P40)) and neurotrophic factors (NT) BDNF, NGF 3 and NT-4 were assessed by ELISA. Phenotyping of lymphocytes (CD3, CD45, CD4, CD8, CD16, CD56, CD20, HLA-DR, CD38, CD127) was performed by multicolored flow cytometry.

A significant increase in levels of IgM, C-reactive protein and cortisol in the blood of patients with schizophrenia compared with healthy groups was found (Table 1).

Most patients with schizophrenia showed an increase in the content of proinflammatory cytokines-IL-8, IL-6 and IFNy (Figure 1).
The greatest increase in the levels of systemic inflammation and cytokines was found in patients with the first psychotic episode. The content of NT was highly variable, but the level of NT-4 and nerve growth factor $\beta$ (NGFB) in most patients was associated with the content of IL-6. At its increased level, the content of NT-4 and NgfB increased, at the normal level of IL-6 it was also within normal limits. More than half of the patients with SCI had normal BDNF levels. At its low level, Ig levels were normal, but levels of CIC, cortisol, IL-8, IL-6 and IL-10 were significantly increased. Also, in the clinical picture in patients with low BDNF symptoms of delirium prevailed, mild hallucinatory syndrome persisted on the background of therapy only in 2 out of 7 people. In cases of normal or elevated BDNF, hallucinatory syndrome was pronounced and prolonged.

Conclusion. Neuroinflammation is considered to be one of the links in the pathogenesis of SCI. According to the literature, antipsychotic drugs have anti-inflammatory and immunomodulatory effects. However, we have found signs of systemic inflammation, activation and dysfunction of the immune system in patients with schizophrenia, despite the therapy. Taking into account the hypotheses of the pathogenesis of schizophrenia, it can be assumed that the preservation of immune disorders and systemic inflammation can participate

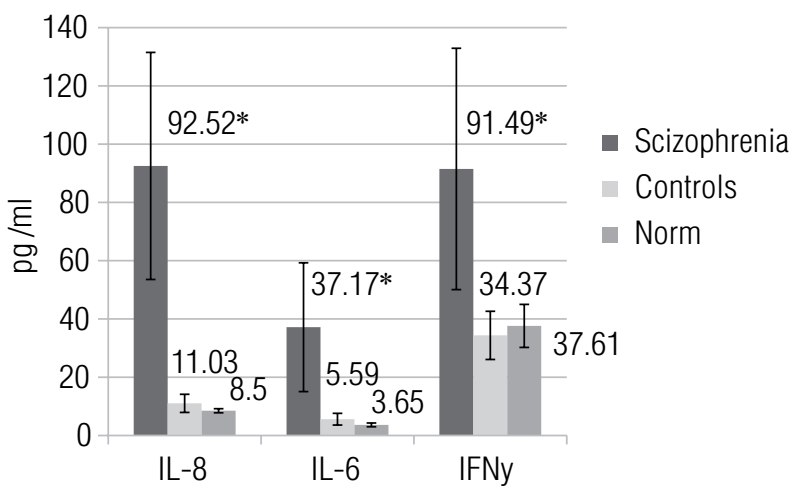

Fig. 1. Levels of cytokines IL-8, IL-6, IFNy in patients with schizophrenia and in healthy volunteers. *significance of differences compared to control, $p<0.05$ 
in the progression of the disease through various ways of neuroimmune interactions. Further studies of the trigger mechanisms of chronic immune activation are needed.
This work was supported in part by the National Research Center "Kurchatov institute" (grant \#1604).

\section{References}

1. Dickinson D, Ramsey ME, Gold JM. Overlooking the obvious: a meta-analytic comparison of digit symbol coding tasks and other cognitive measures in schizophrenia. Arch Gen Psychiatry. 2007;64(5):532-542.

2. Owen MJ, O'Donovan MC. Schizophrenia and the neurodevelopmental continuum: evidence from genomics. World Psychiatry. 2017;16(3):227-235.

3. Goldsmith DR, Rapaport MH, Miller BJ. A meta-analysis of blood cytokine network alterations in psychiatric patients: comparisons between schizophrenia, bipolar disorder and depression. Mol Psychiatry. 2016;21(12):1696-1709. 